\title{
Lingual thyroid associated with hypothyroidism as a cause for short stature
}

\author{
Nitin Kapoor, Sahana Shetty, Nihal Thomas, Thomas Vizhalil Paul
}

Department of Endocrinology, Christian Medical College, Vellore, Tamil Nadu, India

\section{Correspondence to}

Professor Thomas Vizhalil Paul, thomasvpaul@yahoo.com

Accepted 23 October 2014

\section{DESCRIPTION}

A 19-year-old college girl presented with lack of linear growth since 11 years of age, primary amenorrhoea and failure of development of secondary sexual characters. There was no significant history prior to this. On examination, she was a cheerful girl, having a short stature. Her height was $135 \mathrm{~cm}$ (25th centile) and weight $36 \mathrm{~kg}$. She had dry skin with a yellowish tinge. There was no goitre, dysmorphism or syndromic features. Her sexual maturity staging was prepubertal. The rest of the examination was normal except for delayed relaxation of ankle jerks. Her thyroid-stimulating hormone was $150 \mu \mathrm{IU} / \mathrm{mL}$ (normal 0.8-4.2) with a free $\mathrm{T} 4$ of $0.4 \mathrm{ng} / \mathrm{L}$ (normal 0.8-1.8). Her

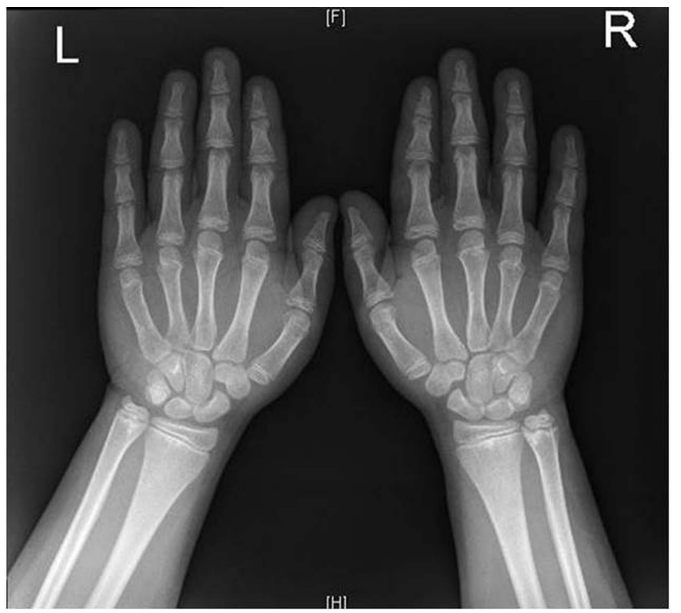

Figure 1 X-ray of the hand showing bone age of 10-11 years. follicle-stimulating hormone and prolactin were $0.8 \mathrm{mIU} / \mathrm{mL}$ and $58 \mathrm{ng} / \mathrm{mL}$ (normal 2-24), respectively. Her bone age was between 10 and 11 years (figure 1) and a technetium ${ }^{99}$ nuclear scan (figure 2) revealed a lingual thyroid (LT) gland along with no thyroid tissue in the neck. Her thyroid antibodies were negative. Her short stature was due to hypothyroidism and primary amenorrhoea was attributed to hyperprolactinaemia secondary to untreated hypothyroidism. The diagnosis in this case was juvenile hypothyroidism associated with thyroid locating in an ectopic position.

Any disruption of the descent during the embryonic development of the thyroid gland will result in ectopic thyroid (most cases are lingual). ${ }^{1}$

The presenting features of LT are dysphagia, dysphonia, bleeding and fullness in the throat, or an incidental finding. ${ }^{2}$ A proportion of patients with LT may be associated with hypothyroidism during their second decade, which may result in delayed puberty and deceleration of growth. Surgery is preferred when there are symptoms such as dysphagia or dyspnoea. ${ }^{3}$

\section{Learning points}

- Lingual thyroid may be associated with hypothyroidism resulting in cases of short stature and delayed puberty.

- The symptoms secondary to lingual thyroid include dysphagia, dysphonia, bleeding and fullness in the throat.

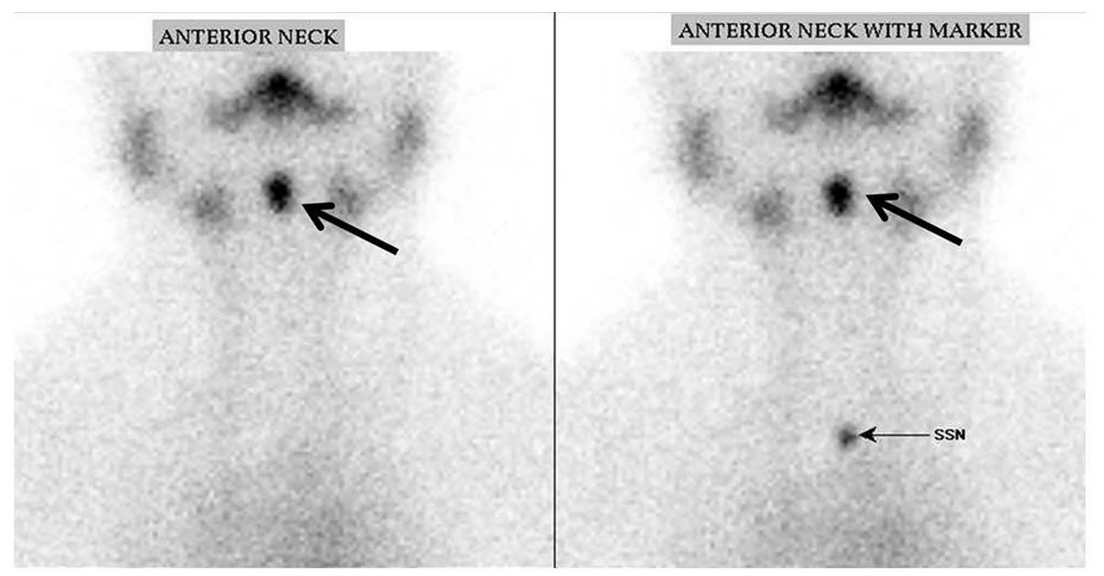

Figure 2 Technetium ${ }^{99}$ nuclear scan displaying a lingual thyroid gland along with no thyroid tissue in the neck. 
Acknowledgements The authors acknowledge Ms Banu Shankar for secretarial help.

Contributors NK and SS wrote the manuscript; NT and TVP reviewed the manuscript; NK, SS, NT and TVP finally approved the manuscript.

Competing interests None.

Patient consent Obtained.

Provenance and peer review Not commissioned; externally peer reviewed.

\section{REFERENCES}

1 Amani Mel A, Benabadji N, Benzian Z, et al. Ectopic lingual thyroid. Indian I Nucl Med 2012;27:124-6.

2 Toso A, Colombani F, Averono G, et al. Lingual thyroid causing dysphagia and dyspnoea. Case reports and review of the literature. Acta Otorhinolaryngol Ital 2009;29:213-17.

3 Williams JD, Sclafani AP, Slupchinskij 0 , et al. Evaluation and management of the lingual thyroid gland. Ann Otol Rhinol Laryngol 1996;105:312-16.

Copyright 2014 BMJ Publishing Group. All rights reserved. For permission to reuse any of this content visit

http://group.bmj.com/group/rights-licensing/permissions.

BMJ Case Report Fellows may re-use this article for personal use and teaching without any further permission.

Become a Fellow of BMJ Case Reports today and you can:

- Submit as many cases as you like

- Enjoy fast sympathetic peer review and rapid publication of accepted articles

- Access all the published articles

- Re-use any of the published material for personal use and teaching without further permission

For information on Institutional Fellowships contact consortiasales@bmjgroup.com

Visit casereports.bmj.com for more articles like this and to become a Fellow 